\title{
CONNECTICUT'S BIRTH CONTROL LAW: REVIEWING A STATE STATUTE UNDER THE FOURTEENTH AMENDMENT**
}

THE power of a state to prohibit the use of contraceptives by married persons is currently being tested before the United States Supreme Court. ${ }^{1}$ Plaintiffs challenge the constitutionality of a Connecticut anticontraceptive statute on the ground that it violates the due process provisions of the fourteenth amendment. Although thirty-four states ${ }^{2}$ and the federal government ${ }^{3}$ have in force some form of birth control legislation, only Connecticut ${ }^{4}$ and Massachusetts ${ }^{5}$ severely restrict legal means of obtaining contraceptives. ${ }^{0}$ The Connecticut statute provides that "any person who uses any drug, medicinal article or instrument for the purpose of preventing conception shall be fined not less than fifty dollars or imprisoned not less than sixty days nor more than one year or both fined and imprisoned." Passed in 1879 as a

*Poe v. Ullman and Buxton v. Ullman, decided below in a single opinion, Buxton v. Ullman, 147 Conn. 48, 156 A.2d 508 (1959), probable jurisdiction noted, 362 U.S. 987 (1960) (Nos. 810 and 811, 1959 Term; renumbered Nos. 60 and 61, 1960 Term), motion to postpone argument until February term granted, 29 U.S.L. WEEK 3101 (Oct. 11, 1960). Mr. Justice Frankfurter took no part in the consideration or decision of the cases. Ibid.

1. Ibid.

2. See statutes collected in Appendix A.

3. 18 U.S.C. $\$ \S 1461-62$ (1958) ; Tariff Act of 1930, 46 Stat. 688, 19 U.S.C. $\$ 1305$ (1958) ; see Note, 50 YaLE L.J. 682 (1941).

4. Conn. Gen. Stat. Rev. \$ 53-32 (1958).

5. Mass. Gen. Laws ANs, ch. 272, $\$ \$ 20-21$ (1956). For judicial interpretation of the statute, see Commonwealth v. Werlinsky, 307 Mass. 608, 29 N.E.2d 150 (1940) ; Commonwealth v. Corbett, 307 Mass. 7, 29 N.E.2d 151 (1940); Commonwealth v. Gardner, 300 Mass. 372, 15 N.E.2d 222 (1938) ; Commonwealth v. Allison, 227 Mass. 57, 116 N.E. 265 (1917). Attempts to write a medical exception into the statute by referendum were defeated in 1942 and 1948. St. John-Stevas, Birth Control and Public Policy 22 (1960) [hereinafter cited as ST. JoHr-STEVAs].

6. The typical statute prohibits the sale and/or advertisement of contraceptives, but contains an exception which allows physicians and often pharmacists to distribute them for "medical" reasons. For a listing and classification of the statutes, see ST. JoHN-SrEvas 82-83; Abortion in the United States 196-99 (Calderone ed. 1958).

States with statutes as prohibitory in language as Connecticut or Massachusetts have permitted birth control clinics. Brief for Planned Parenthood Federation of America as Amicus Curiae, apps. E \& F. The New Jersey statute prohibiting sale of contraceptives "without just cause" was held unconstitutional because of the vagueness of the standard. State v. Kinney Bldg. Drug Stores, Inc., 56 N.J. Super. 37, 151 A.2d 430 (Essex County Ct. 1959). The federal statutes have been read to include an exception for medical purposes. Consumers Union v. Walker, 145 F.2d 33 (D.C. Cir. 1944) ; United States v. One Package, 86 F.2d 737 (2d Cir. 1936). For a history of attempts to amend the federal statutes, see Sulloway, Birth Control and Catholic Doctrine 190-91 n.20 (1959).

7. Conn. Gen. Stat. Rev. § 53-32 (1958). This statute is implemented by a general accessory statute which provides that "any person who assists, abets, counsels, causes, hires or commands another to commit any offense may be prosecuted and punished as if he were the principal offender." Conn. Gen. Stat. Rev. \$ 54-196 (1958). 
result of the moral fervor generated by Anthony Comstock's nation-wide crusade against obscenity and vice, ${ }^{8}$ the statute has survived repeated attempts at amendment and repeal. ${ }^{9}$

The Connecticut statute has survived two challenges to its constitutionality. In State v. Nelson, ${ }^{10}$ the only prosecution under the statute in its 81 -year history, two physicians and a nurse were charged with advising and assisting a married woman to use contraceptives in order to prevent pregnancy and thus preserve her "general health." The trial court sustained demurrers to the informations. The court found that the statute could not be construed to contain an exception which would allow physicians to prescribe contraceptives to married women whose "general health" would be adversely affected by pregnancy. In the absence of such an exception, the court held, the statute was unconstitutional as a deprivation of "individual liberty" without due process. ${ }^{11}$ On appeal, the Supreme Court of Errors of Connecticut reversed, holding that the statute need not include a "general health" exception in order to be a valid exercise of the police power of the state. The question of statutory construction which the court in Nelson recognized but was not required by the facts to consider-"whether an implied exception might be recognized when 'pregnancy would jeopardize life" "12 -was answered two years later in Tileston v. Ullman, ${ }^{13}$ in which a physician sought a declaratory judgment on this issue. The Supreme Court of Errors again refused to read an exception into the statute, holding that the legislature could reasonably find that "abstinence from intercourse is a reasonable and practicable method of preventing the unfortunate consequences [of conception]."14 An appeal to the United States Supreme Court was dismissed on the ground that the plaintiff-physician, by contending solely that the statute deprived his patients of life without due process of law, had failed to assert a denial of his own constitutional rights and therefore lacked standing to challenge the statute. ${ }^{15}$

8. See Haney, Comstockery in America 18-25 (1960).

9. Legislation to amend the statute was introduced in the House and Senate at the biennial sessions of 1923, 1925, 1927, 1931 (twice), 1933, 1935, 1941 (three times), 1943, $1945,1947,1949,1951,1953,1955,1957$, and 1959. In some of these years it passed the House but was defeated in the Senate. Legislation which would have repealed the statute was introduced in 1917, 1927, and 1929. The statute has also withstood six general revisions of the Connecticut statutes, made in 1888, 1902, 1918, 1930, 1949, and 1958. For a complete summary of the legislative history see Brief for Appellee, pp. 3-7, Tileston v. Ullman, 318 U.S. 44 (1943); Buxton v. Ullman, 147 Conn. 48, 56-57, 156 A.2d 508, 513 (1959).

10. 126 Conn. 412, 11 A.2d 856 (1940), Note, 20 B.U.L. Rev. 551 (1940), Note, 31

J. Am. Institute Crim. L. \& Criminology 312 (1940).

11. State v. Nelson, 7 Conn. Supp. 262 (New Haven County Ct. 1939).

12. 126 Conn. at 418,11 A.2d at 859.

13. 129 Conn. 84, 26 A.2d 582 (1942), Note, 23 B.U.L. Rev. 115 (1943), Note, 17

St. John's L. Rev. 122 (1943), Note, 16 So. CaI. L. Rev. 224 (1943).

14. 129 Conn. at 92, 26 A.2d at 586.

15. 318 U.S. 44,46 (1943). 
Poe v. Ullman ${ }^{16}$ is the third test of constitutionality. The appellants in Poe brought independent actions seeking declaratory judgments that the statute violated their rights under the fourteenth amendment. Jane Doe, a married woman, suffers from a number of serious physical and emotional conditions, and in the opinion of her physician another pregnancy will result in irreparable injury and possible death. The second appellants, Paul and Pauline Poe, are husband and wife. Mrs. Poe has given birth to three children, each with multiple congenital abnormalities inconsistent with life, and her physician believes that another pregnancy before the cause of these abnormalities can be identified and corrected would be "extremely disturbing" to the physical and emotional health of both husband and wife. ${ }^{17}$ The trial court sustained a demurrer to both complaints. The Supreme Court of Errors, in affirming, recognized the potential harm which might result from prohibiting the use of contraceptives but concluded that "[this] fact does not make it absolutely necessary for the legislature" to permit their use, even when medically indicated, if a reasonable alternative exists. ${ }^{18}$ The court found "abstinence from sexual intercourse" to be an alternative and refused to investigate its reasonableness beyond the finding that it was not clearly unreasonable. ${ }^{19}$

At the outset, the appeal raises a jurisdictional question: does this action for declaratory judgment present a justiciable case or controversy as required by article III, section 2 of the Constitution? Some doubt may be cast upon the sufficiency of the allegations in Poe by the case of United Pub. Workers v. Mitchell, ${ }^{20}$ in which federal employees sought a declaratory judgment on the constitutionality of the Hatch Act, which prohibits federal workers from participating "in political management or in political campaigns."21 The Supreme Court held that no justiciable case or controversy was presented, because the uncertainty as to the kinds of political activity the appellants meant to engage in made it impossible to determine whether prohibition of this activity would violate their freedom of speech under the first amendment. The holding in Mitchell, however, has been considerably weakened. ${ }^{22}$ In Adler $v$. Board of

16. 147 Conn. 48,156 A.2d 508 (1959). The names of the appellants are fictitious.

17. The final appellant is Dr. C. Lee Buxton, a gynecologist and professor at Yale Medical School; he is the physician of the other appellants. He contends that the Connecticut statute prevents him from practicing his profession "according to the scientific principles on which it is based" and thereby deprives him of liberty and property in violation of the fourteenth amendment. Brief for Appellants, pp. 7, 67-71.

This Note will discuss only the claims of the first two appellants. Because Dr. Buxton is prohibited from prescribing contraceptives only by the general accessory statute, see note 7 supra, his claim will be moot to the extent that the Court allows plaintiffs' claim.

18. 147 Conn. at 58, 156 A.2d at 514 .

19. Id. at $58-59,156 \mathrm{~A} .2 \mathrm{~d}$ at 514 .

20. 330 U.S. 75 (1947).

21. Hatch Political Activity Act, 53 Stat. 1147 (1939), as amended, 5 U.S.C. § 118(i) (1958).

22. See 3 Davis, Administrative Law \& 21.06, at 162-64 (1958); Davis, Starding, Ripeness, and Civil Liberties: A Critique of Adler v. Board of Education, 38 A.B.A.J. 924, 926 (1952). 
Education, ${ }^{23}$ the Court rendered a decision on the merits in a declaratory judgment action brought by parents, teachers, and taxpayers challenging the constitutionality of a New York statute which required discharge of any public school employee who engaged in subversive political activity. Despite a strong dissent by Mr. Justice Frankfurter pointing out that the failure of appellees to allege that they had engaged or intended to engage in prohibited conduct placed the facts of Adler squarely within the "controlling relevance"24 of Mitchell, the Court did not discuss the issue of whether a justiciable case or controversy existed. In the subsequent case of Evers $v$. Dwyer, ${ }^{25}$ the Court explicitly held that an action for declaratory judgment was an appropriate method for testing the constitutionality of a state statute requiring raciallysegregated seating on buses; the complainant was not "bound to continue to ride the Memphis buses at the risk of arrest" in order "to demonstrate the existence of an 'actual controversy' over the validity of the [challenged] statute ...."26 This holding would seem to suggest that actual arrest or prosecution is not a necessary element of a justiciable case or controversy if it is clear from the facts presented that enforcement of a statute will limit an individual's freedom to do "what he claims a constitutional privilege to do without restraint."27 In the present case, the desired conduct of the appellants is definite and specific and would clearly violate the statute. And by demurring to the complaint, the state has admitted appellants' allegation that the state "intends to prosecute any offenses against the Statutes ...."28 Even without this admission, appellants should be entitled to rely on a presumption that the statute will be enforced, despite the fact that in the past the state has not been overly vigorous in prosecuting violations. ${ }^{29}$ Otherwise, the protection of their rights will be made to rest on the continued inaction of state enforcement officers. ${ }^{30}$

Once the jurisdictional obstacle is overcome and the central issue of constitutionality is reached, the Court will be faced with the primary contention of appellant-patients: application of the statute to them results in the creation of serious risks to life and health and therefore violates the fourteenth amendment.

23. 342 U.S. 485 (1952).

24. Id. at 503.

25. 358 U.S. 202 (1958). Although the question of justiciability related to the Federal Declaratory Judgment Act, 28 U.S.C. $\$ 2201$ (1958), it has been uniformly held that the term "actual controversy" is used in the act in the constitutional sense. E.g., Public Service Comm'n v. Wycoff Co., 344 U.S. 237 (1952).

26. 358 U.S. at 204. In its per curiam opinion the Supreme Court found the intention to create a test case "not significant." Ibid.

27. See Borchard, Challenging "Penal" Statutes by Declaratory Action, 52 Yale L.J. 445, 457 (1943).

28. Amended complaint filed February 14, 1959, in Superior Court for New Haven County, Record and Brief, Vol. A-380, p. 5, Buxton v. Ullman, 147 Conn. 48, 156 A.2d 508 (1959).

29. State v. Nelson, 126 Conn. 412,11 A.2d 856 (1940), is the only recorded prosecution in 81 years.

30. See Borchard, supra note 27, at 492; Davis, supra note 22; Note, 61 HARv. L. REv. 1208, 1214 (1948). 
The Connecticut court avoided the constitutional question by finding that the statute did not jeopardize the life or health of married persons.

The scope of the Supreme Court's constitutional analysis of the statute may depend on whether this finding is upheld on review. If life and health are not endangered, the impact of the statute on private conduct might be characterized as relatively inconsequential, similar perhaps to the effect of legislation regulating economic activity. Appellants would then be limited to attacking the statute as arbitrary or capricious. To repel this argument, the state need only demonstrate that the statute was passed in the exercise of a recognized state power and that it bears a reasonable relation to the end sought by the legislature. ${ }^{31}$ On the other hand, if appellants can persuade the Court to find that the statute does increase the risk of death or illness, the state may be forced to demonstrate an overriding interest which can justify this intrusion upon the person. Such a demonstration has, in effect, been required by the Court in cases involving regulation of speech, religion, and other highly regarded liberties. ${ }^{32}$ Whether or not such rights occupy a preferred position in the constitutional hierarchy, at least it can be said that they "come to [the] Court with a momentum for respect lacking when appeal is made to liberties which derive merely from shifting economic arrangements." ${ }^{33}$ Closer judicial examination of the state's interest in these cases is based upon the great importance of the right regulated to the freedom of the individual and to the maintenance of a democratic society. ${ }^{34}$ The Supreme Court has never explicitly applied this rigorous test to legislation which jeopardizes life and health. But if concern for a democratic society rests, as it must, upon the desire to maintain conditions which promote the fullest development and self-realization of

31. See, e.g., Williamson v. Lee Optical Co., 348 U.S. 483, 488 (1955), in which the Court said:

The day is gone when this Court uses the Due Process Clause of the Fourteenth Amendment to strike down state laws, regulatory of business and industrial conditions, because they may be unwise, improvident, or out of harmony with a particular school of thought.

See also Nebbia v. New York, 291 U.S. 502 (1934); Wickard v. Filburn, 317 U.S. 111 (1942); Kauper, Supreme Court: Trends in Constitutional Interpretation, 24 F.R.D. 155, $174-75$ (1958).

32. E.g., NAACP v. Alabama, 357 U.S. 449, 463 (1958) ; Bates v. Little Rock, 361 U.S. 516 (1960) ; West Virginia State Bd. of Education v. Barnette, 319 U.S. 624 (1943); Pierce v. Society of Sisters, 268 U.S. 510 (1925); Meyer v. Nebraska, 262 U.S. 390 (1923). See also Kovacs v. Cooper, 336 U.S. 77, 89 (1949) (collection of cases in concurring opinion of Mr. Justice Frankfurter). See generally BLACK, The People AND THE COURT 215-22 (1960).

33. Kovacs v. Cooper, 336 U.S. 77, 95 (1949) (Frankfurter, J., concurring).

34. E.g., West Virginia State Bd. of Education v. Barnette, 319 U.S. 624, 639 (1943); Martin v. City of Struthers, 319 U.S. 141, $146-47$ (1943) ; Palko v. Connecticut, 302 U.S. 319,327 (1937) (dictum). See also Whitney v. California, 274 U.S. 357, 375-77 (1927) (Brandeis, J., concurring); Richardson, Freedom of Expression and the Function of Courts, 65 HARv. L. REv. 1, 3-7 (1951). 
the individual, maintenance of those conditions would seem to require at least an equal concern for the preservation of life and health.

The duty of the Court to guard against statutes which endanger life and health seems to have been recognized in Jacobson $v$. Massachusetts, ${ }^{35}$ in which the Court warned in dictum that it would not sustain application of a compulsory vaccination statute when such application would result in serious jeopardy to life or health. Such an application of the statute, the Court suggested, would be "so arbitrary and oppressive . . . as to justify the interference of the courts to prevent wrong and oppression."36

Even if the right to life and health deserves constitutional protection, appellants must also demonstrate that the Connecticut statute actually threatens that right. Their opportunity to raise this issue may be foreclosed, however, by the Court's traditional reluctance to reexamine a finding made by a state legislature. ${ }^{37}$ Although in other constitutionally protected areas, such as free speech, the Court probably would not defer to a legislature's finding that certain restraints "do not impair free speech," the Court's exercise of independent judgment in that case could be justified by observing that the necessary components of free speech are a matter of constitutional interpretation. But when the issue is whether a state statute puts life and health in jeopardy, or, perhaps more accurately, whether the existence of the statute increases the risk of harm, the legislature's judgment seems more one of fact. The legislature simply decides whether alternative methods of birth control (such as abstinence) are as effective as the prohibited contraceptive devices. Even in this case, however, it is not clear that the Court should defer. Since the "factual" judgment effectively forecloses further inquiry into a possible constitutional infringement, arguably the state's determination of this issue cannot be binding upon the tribunal ultimately responsible for protecting such rights. ${ }^{38}$. Indeed, the prevention of unreasonable threats to life and health may be so important that the Court should ignore the "reasonable alternative" justification and should weigh the relative importance of the state's interest whenever a statute merely prohibits one among many reasonable methods of preserving health. ${ }^{39}$

35. 197 U.S. 11 (1905).

36. Id. at 38 .

37. See cases cited note 31 stpra.

38. In cases coming to the Supreme Court from state courts, the more closely the so-called issue of fact coincides with and threatens to conclude the ultimate constitutional question in the case, the more intensively the Court seems to "analyze the facts in order that the appropriate enforcement of the federal right may be assured." Norris v. Alabama, 294 U.S. 587, 590 (1935). This approach also seems to have been used in such coerced confession cases as Leyra v. Denno, 347 U.S. 556 (1954) (see especially the dissenting opinion of Mr. Justice Minton) and Blackburn v. Alabama, 361 U.S. 199 (1960), in which lower court findings of "fact" were, in effect, reviewed and reversed.

39. England v. Louisiana State Bd. of Medical Examiners, 259 F.2d 626, 627 (5th Cir. 1958) suggests that "the State cannot deny to any individual the right to exercise a reasonable choice in the method of treatment of his ills ...." 
Of course, a statute may be constitutional despite its threat to life and health if the state's interest is sufficiently important to justify imposition of the peril. The acceptance of military conscription during wartime is perhaps the best evidence of this possibility. ${ }^{40}$ Since the interests of the state and the individual must be balanced, therefore, it seems necessary for the Court to appraise the approximate degree of danger to life and health. A state interest found insufficient to justify legislation creating a serious risk to life and health might be sufficient to justify a less serious threat. Admittedly, decisions involving first amendment freedoms seem not to recognize differing degrees of infringement. They suggest instead that whenever a challenged law is found to abridge a freedom, it must be declared invalid. ${ }^{41}$ But the conclusion that a right is or is not "abridged" may itself be the result of analysis in which the relative weight of both interests are compared. Indeed, any court which recognizes that constitutional rights are not absolutes must employ this comparative weighing at some point in the process of decision.

Whether the Connecticut statute jeopardizes life and health depends upon the consequences of being forced to use methods of birth control other than contraceptives. The Supreme Court, in considering an argument that a Massachusetts vaccination statute was unsafe, ruled that it could not disturb the state legislature's finding if that finding was supported by common knowledge and a respected body of medical opinion. ${ }^{42}$ Tested by this standard, the judgment imputed to the Connecticut legislature-that alternative methods of preventing conception are equally effective-cannot withstand review. The alternative specifically suggested by the Connecticut court was abstinence. Abstinence, however, is a result, not an alternative. What the statute really relies on as an alternative is the continued good judgment, intelligence, and physical and emotional control of man and wife living together. If the propensities and weaknesses of human nature are considered relevant to assessing the risk of injurious pregnancy, the efficacy of abstinence as an alternative is doubtful. ${ }^{43}$ Furthermore, even if prolonged abstinence were possible, it is frequently identified by psychiatric and medical authorities as the cause of a wide range

40. See Selective Draft Law Cases, 245 U.S. 366 (1918). For judicial reliance on this analogy in similar situations, see Buck v. Bell, 274 U.S. 200, 207 (1927) (Holmes, J.). See also Silesian-American Corp. v. Markham, 156 F.2d 793, 798 (2d Cir. 1946) (L. Hand, J.).

41. See, e.g., Kovacs v. Cooper, 336 U.S. 77 (1949).

42. Jacobson v. Massachusetts, 197 U.S. 11, 30 (1905).

43. See, e.g., Horney, The Neurotic Personality of Our Times 158-59 (1937); Stone \& Stone, A Marriage Manual 105-06 (1953).

A Connecticut court makes the following remark:

Do the frailties of human nature and the uncertainties of human passion render [abstinence] impracticable? That is a question for the legislature, and we cannot say it could not believe that the husband and wife would and should refrain when they both knew that intercourse would very likely result in a pregnancy which might bring about the death of the wife.

Tileston v. Ullman, 129 Conn. 84, 92, 26 A.2d 582, 586 (1942). 
of physical and emotional illnesses, ${ }^{44}$ effects which must also be considered in evaluating the total impact of the statute on life and health. Other alternatives also seem unsound. Medical opinion regards the rhythm method of birth control as unreliable ;5 $^{\mathbf{5}}$ its use always involves a substantial possibility of pregnancy both because of unpredictible physiological factors and because of the requirement of long periods of abstinence in order to maximize its effectiveness. Withdrawal, or coitus interruptus, is also believed unreliable; moreover, this practice can result in serious emotional disturbances. ${ }^{46}$ Abortion, of course, creates far greater dangers to the physical and emotional health of the mother than would the use of contraceptives ${ }^{47}$ indeed, in many cases in which a woman's health makes pregnancy undesirable, an abortion would be even more dangerous than pregnancy. ${ }^{48}$ Sterilization, while undoubtedly reliable, involves the irrevocable surrender of the possibility of having children. This alternative seems unreasonable, especially since the physical, genetic, or emotional conditions which currently make pregnancy unwise may subsequently be rendered curable through medical science or eliminated by a change in the circumstances of the parties. ${ }^{49}$

After determining the statute's effect upon the individual, the Court must then examine the state interests advanced in support of the statute. The two possible levels of judicial inquiry should again be distinguished. The Court must first determine that the statute is not an arbitrary or capricious exercise of state power. If the statute affects a constitutional right, the Court must go beyond this initial test and weigh the state's interest against the possible infringement.

The only state power from which the statute can draw its justification is the police power to regulate public health, welfare, and morals. Despite the absence of legislative statements indicating its purpose, the statute might be

44. See Fenicher, The Psychoanalytic Theory of Neuroses 187-88, 455 (1945); Dickinson, Techniques of Conception Control 40 (1950). See collection of authorities in Brief of Planned Parenthood Federation of America as Amicus Curiae, app. D.

45. See Jannex, Medical Gynecology 398 (1950); Decker \& Decker, Practical Office Gynecology 320 (1956) ; St. JoHN-Stevas 49. For a survey of physicians' opinions regarding the "reliability" of contraceptive devices and methods, see 12 Human Fertility, No. 1, March, 1947, quoted in Brief for Appellants, p. 15.

46. See Brief for Appellants, p. 15; Kroger \& Freed, Psychosomatic Gynecology 276 (1951).

47. Abortion to preserve the health of the mother is legal in Connecticut. Cons. GeN. Stat. Rev. § 53-29 (1958).

48. This was the case, for example, with Appellant Jane Doe. See Brief for Appellants, p. 5.

49. The correction of such conditions is regarded as possible in the instant case. Brief for Appellants, p. 7.

Moreover, sterilization has been looked upon by the Court, in other contexts, with great skepticism. See Skinner v. Oklahoma $e x \mathrm{rel}$. Williamson, 316 U.S. 535 (1942) (which may tacitly overrule Buck v. Bell, 274 U.S. 200 (1927)) ; Pritchett, The Amarrican Constitution 562-63 (1959) ; Berns, Buck v. Bell: Due Process of Law?, 6 Western Poltrical Q. 762 (1953). 
regarded as an attempt to foster each of these broadly defined goals. As a public health measure, the statute would be predicated on a finding that contraceptives are inimical to health. The due process test of reasonableness which such public health statutes must meet has been considered in a number of Supreme Court decisions. In Jacobson v. Massachusetts ${ }^{50}$ the Court upheld a compulsory vaccination law when it found that the legislature, in choosing between two divergent bodies of medical opinion on the efficacy and safety of vaccination, had chosen the theory which "accords with the common belief and is maintained by high medical authority." 51 And in Lambert $v$. Yellowley ${ }^{52}$ the Court sustained a federal statute limiting the use of spiritous liquors for medicinal purposes, noting that such a limitation "in the presence of the well known diverging opinions of physicians, cannot be regarded as arbitrary or without a reasonable basis."53 From the fact that the Court has upheld such statutes only after determining that a respected element of the medical profession endorsed the legislature's theory, it may reasonably be inferred that a statute which lacks such endorsement would be held unreasonable. Since the medical profession is virtually unanimous in considering the use of contraceptives an effective method of medical treatment which is in no way adverse to health, ${ }^{54}$ the Connecticut anticontraceptive law, as a public health measure, would probably be struck down as lacking a reasonable basis for enactment. Thus the question of whether the statute infringes a constitutional right would never be reached.

Alternatively, the Connecticut statute may be viewed as an exercise of the state's police power to promote the welfare of its citizens. In State v. Nelson the Supreme Court of Errors of Connecticut noted that "if . . . a purpose [of the anticontraceptive statute] was to promote a maintenance and increase of population, that would not be an inadmissible motive. . ." 55 This explanation of the statute strains credulity, especially in view of the fervid moral background of the statute. ${ }^{50}$ Nevertheless, the statute does have a rational nexus to population growth, and population is a valid state concern. Nor would it be arbitrary to apply the statute without exception, since, as one Connecticut

50. 197 U.S. 11 (1905).

51. Id. at 30 .

52. 272 U.S. 581 (1926).

53. Id. at 595. See also Everard's Breweries v. Day, 265 U.S. 545, 561-63 (1924) (lack of consensus among medical opinion).

54. The effectiveness and safety of the use of contraceptives was conceded by both the state and the Supreme Court of Errors. Buxton v. Ullman, 147 Conn. 48, 57, 58, 156 A.2d 508, 512, 514 (1959). A collection of 844 medical articles on the subject is included in Brief of Planned Parenthood Federation of America as Amicus Curiae, app. C. For the minority view that use of contraceptives is medically injurious, see MoORE, THE CASE Against Birth Control 28 (1931); Sutherland, Laws of Life 41, 47 (1935), cited in St. John-Stevas 45.

55. 126 Conn. 412, 425, 11 A.2d 856, 862 (1940).

56. See note 8 supra and accompanying text. 
court has suggested, permission to issue contraceptive devices for medical purposes would put such devices in the hands of less ethical practitioners and might "extend the field of exemption indefinitely." the statute, however, raises squarely the constitutional issue of danger to life and health, because it admits as its basic premise that conception is more likely when the use of contraceptives is prohibited. The relative importance of the statute in promoting population growth does not seem sufficient to justify infringement of a constitutionally protected right. The fluctuations of a state's population level in a mobile society are so dependent upon such factors as a favorable economic climate and adequate civic facilities that any influence which prohibiting the use of contraceptives would have is probably lost in the totality of other factors.

The most plausible approach to the Connecticut statute is to characterize it as an exercise of the state's police power to promote the public morals. The availability of contraceptives can be seen as encouraging conduct, such as adultery and fornication, which the state considers harmful to the community. It is claimed that making contraceptives unavailable reduces the incidence of these acts by increasing the fear of illegitimate pregnancy. ${ }^{58}$ Under this interpretation, the statute appears to be a rational measure ${ }^{59}$ directed toward a problem of recognized state concern. If the statute impinges on a constitutionally protected right, however, it will be relevant to consider whether it is a necessary means to achieve the state's objective. It has been argued that because Connecticut has criminal statutes prohibiting adultery and fornication, ${ }^{60}$ the anticontraceptive statute is cumulative and not central to the prevention of these evils. ${ }^{61}$ It is not clear, however, which of these two methods of prevention is ancillary to the other. Since adultery and fornication statutes are largely ineffective because of the difficulty of detection and enforcement, prohibition of the use and sale of contraceptives may well be the most effective method of control.

The balance of state and individual interests may tip decisively in favor of the individual's right, however, if the Court, in weighing the state's interest, considers only the interest of the state in applying the statute to persons like

57. State v. Nelson, 126 Conn. $412,425,11$ A.2d 856, 862 (1940).

58. In State v. Nelson, 126 Conn. at 424,11 A.2d at 861 , the court said:

$[N]$ ot all married people are immune from temptation or inclination to extra-marital indulgence, as to which risk of illegitimate pregnancy is a recognized deterrent . . . .

See also Appeilees' Brief, p. 14, Tileston v. Ullman, 318 .U.S. 44 (1943) which claims that "the general availability of such articles would ... facilitate dissolute action among unmarried people...."

59. The deterrent effect claimed receives some support from available data. See KINsey, Sexual Behavior in the Human Female 332 (1953).

60. Conn. Gen. Stat. Rev. §§ 53-218, 53-219 (1958).

61. 58 Mice. L. Rev. 929, 931 (1960) ; cf. Schneider v. New Jersey, 308 U.S. 147 (1939). 
the appellants in Poe. While the legislature's fear of creating an uncontrollable exemption furnishes a rational basis for refusing to allow a medical exception, this fear may not be a sufficiently compelling reason when weighed against the resulting threat to life and health. A similar problem was considered in Butler v. Michigan, ${ }^{62}$ in which the Supreme Court reversed a state court conviction based upon a statute prohibiting the sale of literature which tended to corrupt the morals of youth. "We have before us legislation not reasonably restricted to the evil with which it is said to deal," the Court noted. ${ }^{63}$

The incidence of this enactment is to reduce the adult population of Michigan to reading only what is fit for children. It thereby arbitrarily curtails one of those liberties of the individual ... that history has attested as [one of] the indispensable conditions for the maintenance and progress of a free society. ${ }^{64}$

While the Supreme Court can dispose of these cases by finding that the Connecticut statute jeopardizes life or health in violation of the fourteenth amendment, a more sweeping constitutional defect in the statute has been suggested in the briefs. The American Civil Liberties Union, as amicus curia, urges that the statute infringes upon a right to privacy guaranteed by the fourteenth amendment and is therefore unconstitutional as applied to all married persons. ${ }^{65}$ The Court has expressed concern in the past about the privacy of the individual and the privacy of the home. This has been particularly evident in fourth amendment decisions which contain the most explicit recognition of the integrity of the home. ${ }^{66}$ The Court has also spoken, in Public Utilities Comm'n $v$. Pollak, ${ }^{67}$ of the existence of a right to privacy in the context of fifth amendment due process. In upholding the playing of radio programs on a commercial bus line in the District of Columbia, the Court observed that "however complete his [the bus rider's] right of privacy may be at home, it is substantially limited by the rights of others when its possessor ... rides in a public conveyance." 68 A passenger in a public vehicle, the Court said, does not possess "a right of privacy substantially equal to the privacy to which he is entitled in his own home." 09 But these dicta concerning overt forms of intrusion furnish no basis for suggesting the existence of a right to

62. 352 U.S. 380 (1957).

63. Id. at 383 .

64. Id. at 383-84. See also Paramount Film Distrib. Corp. v. City of Chicago, 172 F. Supp. 69, 72 (N.D. Ill. 1959).

65. Pp. 6-16. See also Brief for Appellants, pp. $28-29$.

66. See Frank v. Maryland, 359 U.S. 360, 366 (1959); Wolf v. Colorado, 338 U.S. 25, 27 (1949) ; cf. Irvine v. California, 347 U.S. 128, 145-46 (1954) (Frankfurter, J., dissenting).

67. 343 U.S. 451 (1952).

68. Id. at 464. See also Brandeis \& Warren, The Right to Privacy, 4 Harv. L. Rev. 193 (1890); Griswold, The Right To Be Let Alone, 55 Nw. U.L. Rev. 216 (1960).

69. Ibid. But see Black, He Cannot Choose But Hear: The Plight of the Captive Auditor, 53 Colum. L. Rev. 960 (1953). 
privacy so sweeping in its terms that it would encompass the regulatory intervention of the anticontraceptive statute. Nor do they suggest any guides for defining and limiting so broad a right.

The indiscriminate breadth of this right-to-privacy approach tends to obscure a more specific constitutional objection to this particular statute-the fact that through this law the state interferes with and restricts the sexual relationship of husband and wife. ${ }^{70}$ It is difficult to imagine any area of human activity which more reasonably ought to be beyond the reach of the state. Already included among the liberties of the fourteenth amendment is the right of parents to direct the education of their children, established in Meyer v. Nebraska ${ }^{71}$ and in Pierce v. Society of Sisters. ${ }^{72}$ The Connecticut statute impinges upon a privilege far more basic to the individual's fulfillment and well being and to the protection of the married state than the liberty established in Meyer and Pierce. Justice Brandeis, in his dissent in Olmstead $v$. United States, expressed the fundamental importance of this area of human activity:

The makers of our Constitution undertook to secure conditions favorable to the pursuit of happiness. They recognized the significance of man's spiritual nature, of his feelings and of his intellect. They knew that only a part of the pain, pleasure and satisfactions of life are to be found in material things. They sought to protect Americans in their beliefs, their thoughts, their emotions and their sensations. They conferred, as against the Government, the right to be let alone-the most comprehensive of rights and the right most valued by civilized men. ${ }^{73}$

Recognition of either the right to privacy or the more narrow marital right will call for a balancing of state and individual interests different than that involved when a right to life and health is made the basis of constitutional objection. Rather than carving out an exception for persons whose life and health are endangered, the Court would have to hold the statute unconstitutional as applied to all married persons-in effect invalidating the entire statute. Thus the consequences to the state's anticontraceptive policy are far more serious. By the same token, however, violation of the right to privacy or the marital right is unequivocal and is not tempered by the comparison of statistical probabilities peculiar to an infringement of the right to life and health.

\footnotetext{
70. See 58 Mich. L. Rev. 929 (1960).

71. 262 U.S. 390 (1923).

72. 268 U.S. 510 (1925).

73. 277 U.S. 438,478 (1928).
}

\section{Appendix A: Birth Control Iegislation}

ARIz. Rev. Stat. AnN. § 13-213 (1956); Ark. Stat. ANn. \$§ 82-944 to 82-954 (1947); Cal. Bus. \& Prof. Code $\$ \S 601$, 4301-25; Colo. Rev. Stat. ANN. $\$ \$ 40-9-17,66-10-3$ to 66-10-12 (1953) ; Conn. Gen. Stat. Rev. § 53-32 (1958) ; DeL. Code ANN. tit. 16, § 250104 (1953) ; HawaIn Rev. Laws $\S 8155-73,302 A-1$ to 302A-3 (1955); Idago Code AnN. 
$\S \S 18-603,39-801$ to $39-810$ (Supp. 1959) ; IND. ANN. Stat. $\$ \S 9-601,10-2803$ to 10-2804 (Supp. 1960) ; Iowa Code Anv. \$§ 725.5 to 725.10 (1950) ; Kan. Gen. Stat. AnN. § 211101 (1949); Ky. Rev. Stat. Ann. $\$ 214.190$ to 214.270 (1953) ; La. Rev. Stat. AnN. $\S 14.88$ (1951) ; Me. Rev. Stat. Ans. ch. 134, § 11, ch. 25, § 114 (1954); Md. ANN. Code art. 27, $\S 41$ (1957) ; Mass. Ans. Laws ch. 272, $\$$ 20, 21 (1956) ; Mich. Stat. AnN. $\S 28.229$; MrnN. Stat. Ann. $\$ \$ 617.25$ to 617.27 (1947); Miss. Code ANN. $\$ 2289$ (1957) ; Mo. Rev. Stat. \& 563.300 (1949) ; Mont. Rev. Codes Ann. \$§ 94-3609, 94-3616 to 94-3619 (1949) ; Neb. Rev. Stat. Ann. \$\$ 28-423, 71-1104 to 71-1114 (1958) ; Nev. Rev. Stat. $\$ \S 202.190,202.210-202.230$ (1956) ; N.J. Stat. ANN. $\$ \S 2 A: 170-76$ (1953); New York Pen. Law §§ 1142 to 1145 ; N.C. Gen. Stat. § 14-194 (1953); Ohio Rev. Code Ans. $\$ \$ 2905.32$ to 2905.37 (Page 1953) ; ORE. Rev. Stat. $\$ \S 435.010$ to 435.130 , 435.990 (1959) ; Pa. Stat. AnN. tit. 18, § 4525 (1945) ; S.D. Code § 13.1726 (1952); Utal Code ANN. §§ 58-19-1(f), 58-19-2 to 58-19-11 (1953); Vt. Stat. ANN. tit. 36, $\S 7323$ (1947); Wash. Rev. Code $\$ \$ 9.68 .030,18.81 .010$ to 18.81 .080 (1951); Wis. Stat. ANN. § 151.15 (1957). See also P.R. LAws ANN. tit. 10, § 315, tit. 24, §§ 201-03, tit. 33, $\$ \S 1051-52$ (1954). 